\title{
The Time of Floral Induction in the Olive
}

\author{
R. Fernandez-Escobar and M. Benlloch \\ Departamento de Agronomia, Universidad de Córdoba, Apdo. 3048, 14080 Córdoba, Spain
}

C. Navarro

Departamento de Olivicultura, CIDA, Apdo, 240, 14071 Córdoba, Spain

G.C. Martin

Department of Pomology, University of California, Davis CA 95616

Additional index words. alternate bearing, flowering, fruit removal, gibberellic acid, Olea europaea, paclobutrazol,

seed destruction

\begin{abstract}
G A}_{3}$ scaffold injections applied between May and November to nonbearing olive (Olea europea L.) trees inhibited flowering the following year, increased shoot width when applied in May, June, and July, and increased inflorescence length when applied in November and February. Fruit removal and seed destruction were effective in improving the return bloom in 'Manzanillo' olives when done before endocarp sclerification. Depending on-the year, endocarp sclerification takes place 7 to 8 weeks after full bloom (AFB), usually about 1 July. Fruit removal had no effect on flowering when done after this time. Scaffold injection of paclobutrazol applied to bearing trees between May and September did not affect flowering the following year. The results of our research supports the hypothesis that olive flower induction occurs around the time of endocarp sclerification. Chemical names used: gibberellic acid $\left(\mathrm{GA}_{3}\right)$, (2RS,3RS)-1-(4-chlorophenyl)-4-dimethyl-2-1,2-4-triazol-1-yl) pentan-3-ol(paclobutrazol).
\end{abstract}

Alternate bearing affects many fruit tree species, including olive, and is characterized by a large crop load in the "on" year followed by a small crop in the "off" year. Lack of flower bud formation during the on year is the common characteristic of most alternate-bearing species, including olive (Monselise and Goldschmidt, 1982). The mechanism of alternate bearing is unknown, but environmental conditions and endogenous factors affect flower induction (Bernier, 1988; Monselise and Goldschmidt, 1982). From a practical standpoint, fruit thinning is the best available technique to reduce alternate bearing problems in many species.

Flower induction may be controlled by seeds produced during the on year, Chan and Cain (1967) found in the 'Spencer Seedless' apple that seeded fruits inhibited flowering the following year while seedless fruit did not. These results were confirmed by Stutte and Martin (1986) in olive, where seed destruction before endocarp sclerification promoted flower formation compared to controls with seed. The prevailing interpretation of these experiments is that seed-produced compounds are transported to buds and are responsible for inhibiting flower induction. As with all crops, populations of fruit must be reduced early to increase the size of remaining fruit. For olive such fruit removal should be done before July (Drobish, 1930).

Determining the time of flower bud induction (changes in gene expression responsible for floral initiation) is important for determining possible causes of alternate bearing and for developing management practices to correct alternate bearing. The exact time of induction in olive is unknown. However, several studies indicate that environmental factors during winter have a role in flower induction and subsequent initiation (Badr and Hartmann, 1971; Hackett and Hartmann, 1967; Hartmann and Whisler, 1975). The interpretation given these investigations states that evocation events are temperature dependent. Recently, Pinney and Polito (1990) have developed new procedures showing that flower initiation of olives occurs as early as

Received for publication 13 June 1991. Accepted for publication 29 Oct. 1991 This research was supported in part by CYCYT Project PA 86.0092. The cost of publishing this paper was defrayed in part by the payment of page charges. Under postal regulations, this paper therefore must be hereby marked advertisement solely to indicate this fact.
November in California, well before significant chilling has occurred. On the basis of these results, the role of winter chilling needs re-evaluation; are low temperatures necessary for induction and initiation, or just for breaking dormancy of buds previously initiated, as occurs in other fruit tree species? Recent results obtained by Rallo and Martin (1991) support the latter hypothesis.

The objective of our investigation was to test the hypotheses that olive floral induction and early phases of initiation occur before winter dormancy and that gibberellins from seeds can alter evocation processes.

\section{Materials and Methods}

Olives flower on 1-year-old wood and display two inflorescences per node, which bloom in May. Vegetative growth starts by April each year, and buds are evident in leaf axils soon thereafter.

$G_{3}$ and paclobutrazol. These experiments were designed using bearing and nonbearing 'Manzanillo' trees to test the hypothesis that gibberellins play a role in inhibiting flower formation.

Paclobutrazol and $\mathrm{GA}_{3}$ were applied by scaffold injection to avoid problems of penetration of foliar-applied chemicals (Leon and Bukovac, 1978). The injection method used was that described by Navarro et al. (1992). In brief, test solutions of 200 to $250 \mathrm{ml}$ were placed under pressure in a latex tube. The tube was connected to a plastic injector that was fixed in a hole drilled into the scaffold. To avoid problems of insolubility, paclobutrazol was dissolved in methanol, the solution was centrifuged, water was added to dilute the methanol to $5 \%$, and the solution was vacuum filtered.

In the first group of experiments, conducted in 1985, the effects of exogenous $\mathrm{GA}_{3}$ injections on vegetative growth and return bloom were examined using 'Manzanillo' trees in the off year and grown in the experimental orchard, Univ. of California at Davis. Experiments were repeated in the experimental farm of Alameda del Obispo at Córdoba, Spain, in 1987 and 1988. The trees in both sites were expected to produce flowers the

Abbreviation: AFB, after full bloom. 
next year and $\mathrm{GA}_{3}$ was expected to inhibit flowering. Trees were established in randomized block experiments consisting of five treatments in 1985 and 1988 and six treatments in 1987 with four replications. The treatments were an untreated control and 1000-ppm $\mathrm{GA}_{3}$ injections at 5, 7, or 8 weeks AFB in 1985; at 2, 6, 9, 23, or 38 weeks AFB in 1987; and at 7, 9, 18, or 28 weeks AFB in 1988. Treatments were applied at random to separate scaffolds of each tree, which served as a replicate. To reduce variability, scaffolds of $7-$ to $19-\mathrm{cm}$ cross-sectional area in 1985 and of 38- to 64-cm cross-sectional area in the subsequent years were selected. Each year 10 to 25 shoots were tagged for measurement of shoot width and length of each scaffold.

In the second group of experiments, the effects of exogenous paclobutrazol injections on vegetative growth and return bloom were examined; we again used bearing 'Manzanillo' trees growing in the same experimental orchards. These trees were not expected to flower the next year due to a large fruit population. If gibberellins inhibit flowering, then paclobutrazol treatment, which inhibits gibberellin synthesis (Hedden and Graebe, 1985), should result in flower induction. For this logic to be correct, paclobutrazol would need to move into the seed to inhibit GA synthesis. According to G. Costa (personal communication), paclobutrazol may not be transported into olive fruit or seed to any significant extent. Heavily blooming trees were established on randomized block experiments consisting of four treatments in 1985 and 1988, and five treatments in 1986 and 1987 with four replications. The treatments were an untreated control and applications of $200 \mathrm{ppm}$ paclobutrazol at 5, 7, or 13 weeks AFB in 1985; at 6, 7, 9, 11 weeks AFB in 1986; at 2, 6, 8, 10 weeks AFB in 1987; and at 7, 9, or 18 weeks AFB in 1988. Treatments were applied as described in the $\mathrm{GA}_{3}$ experiments.

Vegetative growth was determined following GA and/or paclobutrazol treatment, and the number of subsequent inflorescences produced on tagged shoots of each scaffold was recorded in May of the year following treatments. Percent return bloom was determined using:

$$
\begin{gathered}
\% \text { return bloom }=[(\text { no. of inflorescences }) \\
(2 \times \text { no. of nodes })-1] \times 100
\end{gathered}
$$

Fruit removal and seed killing. These experiments were designed to test the hypothesis that fruit removal and/or seed destruction before the flower induction period would promote flowering the following season. For the 1985 experiment, six olive cultivars that have similar alternate-bearing features were chosen with a range of small to large fruit. The cultivars, growing at the Univ. of California experimental orchard, were: 'Sevillano' and 'Ascolano' (large fruits); 'Manzanillo' and 'Picual' (medium fruits); and 'Koroneiki' and 'Rubra' (small fruits). For 'Manzanillo', trees with large flower populations were established in a randomized block experiment consisting of five treatments and four single-tree replicates. The treatments were fruit removal at 2, 4, or 6 weeks AFB, seed kill at 6 weeks AFB, and a control. For the other culivars, a randomized block experiment included two treatments of two or four single-tree replicates: control and seed kill at 6 weeks AFB. Seeds were destroyed by puncturing the distal end of the fruit with a 1.6cm-long $0.5 \mathrm{~mm}$ diameter (25 gauge) needle as described by Stutte and Martin (1986). The treatments were applied at random to several hundred fruits on scaffolds that were 7 to $19 \mathrm{~cm}$ in cross-sectional area. In 1987, heavily blooming 'Manzanillo' trees growing in the experimental farm of Alameda del Obispo at Córdoba were selected for a randomized block experiment consisting of six treatments and four replications. Fruits were removed from scaffolds of 38 - to $64-\mathrm{cm}$ cross-sectional area at $4,6,9,19,32$, or 41 weeks AFB. For each scaffold, 10 to 25 shoots were tagged for determination of the following: 1) for all cultivars, the number of fruits present the day of treatment; at harvest, the remaining fruit were counted and weighed;2) the percentage of mature fruits (color change from green to purple) was determined at harvest in 'Manzanillo', 'Rubra', and 'Sevillano' cultivars; 3) the length of the current season's shoot growth and the number of nodes (a factor in calculating return bloom) formed on tagged shoots were recorded just after harvest; and 4) the number of inflorescences produced was recorded before anthesis in May of the following year. The endocarp sclerification period was determined for each cultivar and year of experiment. The onset of that period was established when resistance to puncturing was evident, and the end of the period when the endocarp was impossible to cut with a knife.

The dates for full bloom for each cultivar and year were: 'Manzanillo' 14 May 1985, 1 May 1986, 1 May 1987, and 6 May 1988; 'Sevillano' 15 May 1985, 'Ascolano' 14 May 1985, 'Picual' 14 May 1985, 'Koroneiki' 14 May 1985, and 'Rubra' 16 May 1985.

Analyses of variance were performed on the data from each experiment. All percentage values were transformed using the arcsin of the square root before analysis. Where a significant $F$ test was observed, regression analyses were performed for the quantitative treatments. Mean separation between control and each other treatment was obtained by F test.

\section{Results}

Effect of $\mathrm{GA}_{3}$ and paclobutrazol on flowering. $\mathrm{GA}_{3}$ injections resulted in a reduction of return bloom, as compared to untreated nonbearing trees in the 1987 and 1988 experiments, whereas no significant differences were observed in 1985 (Fig. 1A). Lack of significance in 1985 experiments was due to the high variability obtained, expressed by the $\mathrm{CV}(\mathrm{CV}=90.0 \%)$, and because return bloom of control trees was lower than expected. The treatment reduced bloom when applied between 2 and 9 weeks
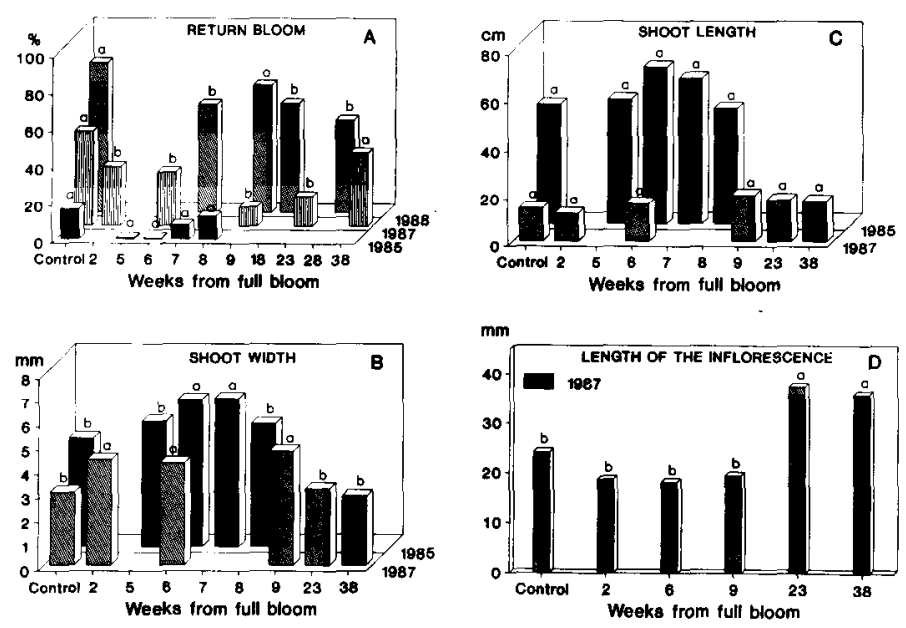

Fig. 1. Effect of GA, injected between 2 and 38 weeks AFB in 198588 on return bloom and vegetative growth in nonbearing 'Manzanillo' olives. Contrast for control vs. each GA treatment by $\mathrm{F}$ test, indicated by letters. Trends for the GA treatments were: (A) Quadratic $(P=0.001)$ in 1987 and nonsignificant in 1985 and 1988 ; (B) linear $(P=0.001)$ or quadratic $(P=0.01)$ in 1987 and nonsignificant in 1985; (C) nonsignificant in 1985 and 1987; (D) linear $(P=0.001)$ or cubic $(P=0.01)$. 
AFB and also when applied 18 to 28 weeks AFB, but there was no significant difference with control trees when $\mathrm{GA}_{3}$ was injected in February, 38 weeks AFB.

$\mathrm{GA}_{3}$ also affected vegetative growth. Shoot width was significantly increased when $\mathrm{GA}_{3}$ was injected 2 or 9 weeks AFB in 1987, whereas injections at 23 and 38 weeks AFB were ineffective (Fig. 1B). A similar response was observed in 1985. GA treatment did not affect shoot length (Fig. 1C). However, some extremely long shoots and growth in a zig-zag fashion were observed with $\mathrm{GA}_{3}$ treatments, particularly when applied in June and July. This aberration was observed only in a few shoots of the treated scaffolds.

$\mathrm{GA}_{3}$ injections in Nov. and Feb. 1987 increased the length of the inflorescence, whereas applications in May, June, and July did not (Fig. 1D). GA injections affected neither fruit set nor pistil abortion the year following treatment (data not shown).

Paclobutrazol did not affect return bloom or shoot length (data not shown). In 1985, shoot length appeared to be enhanced when paclobutrazol was applied in midsummer; this unexpected response was not observed in subsequent years. Also, paclobutrazol did not affect final fruit set or fruit size (data not shown). In this group of experiments, the high variability of return bloom among controls made comparison among years impossible.

Effect of fruit removal and seed kill on return bloom. Fruit removal within 6 weeks of full bloom significantly improved return bloom. Some effect was evident after 9 weeks, but none thereafter (Fig. 2A). Thus, the presence of fruits inhibits flowering. Also, fruit removal at early stages of fruit development, before endocarp sclerification, promotes flowering the following year. Early fruit removal also increased current-year shoot length in the 1987 experiment (Fig. 2B).

Killing the seed at 6 weeks AFB improved return bloom in 'Manzanillo' but did not affect flowering in the other cultivars studied (Table 1). Seed destruction stimulated abscission and reduced fruit size in several cultivars. Our previous experience indicated that abscission can be avoided if seed is killed just before endocarp sclerification. Our seed-kill treatments were done marginally early, 2 weeks before endocarp sclerification. Killing the seed also resulted" in early maturity of the fruits, suggesting that absence of seeds or wounding accelerates fruit development. Shoot length was not affected by the treatment (data not shown).

\section{Discussion}

Exogenous applications of gibberellins inhibit flowering in several fruit tree species (Martin, 1983). Similarly, flowering was inhibited when $\mathrm{GA}_{3}$ was injected into olive trees (Fig. 1), the inhibitory effect varying with timing. Whereas $\mathrm{GA}_{3}$ inhibited flowering when injected any time from May to November, shoot width was affected only when $\mathrm{GA}_{3}$ was injected near the time of endocarp sclerification. Later injections increased inflorescence length. Kachru et al. (1971) reported that $\mathrm{GA}_{3}$ inhibited flowering in mango (Mangifera indica L.) when applied before flower primordia formation but increased the length of the inflorescence when applied after primordium initiation. Also, Lord and Eckard (1987) found that $\mathrm{GA}_{3}$ caused reversion of flowering buds in orange Citrus sinensis L. when applied before sepal formation. We observed that injections of $\mathrm{GA}_{3}$ in November, during floral initiation (Pinney and Polito, 1990), inhibited flowering and increased the length of the few inflorescences formed the next year. Applications in February, just before floral differentiation (Hartmann, 1951), increased the length of the inflorescence but had no effect on return bloom. These
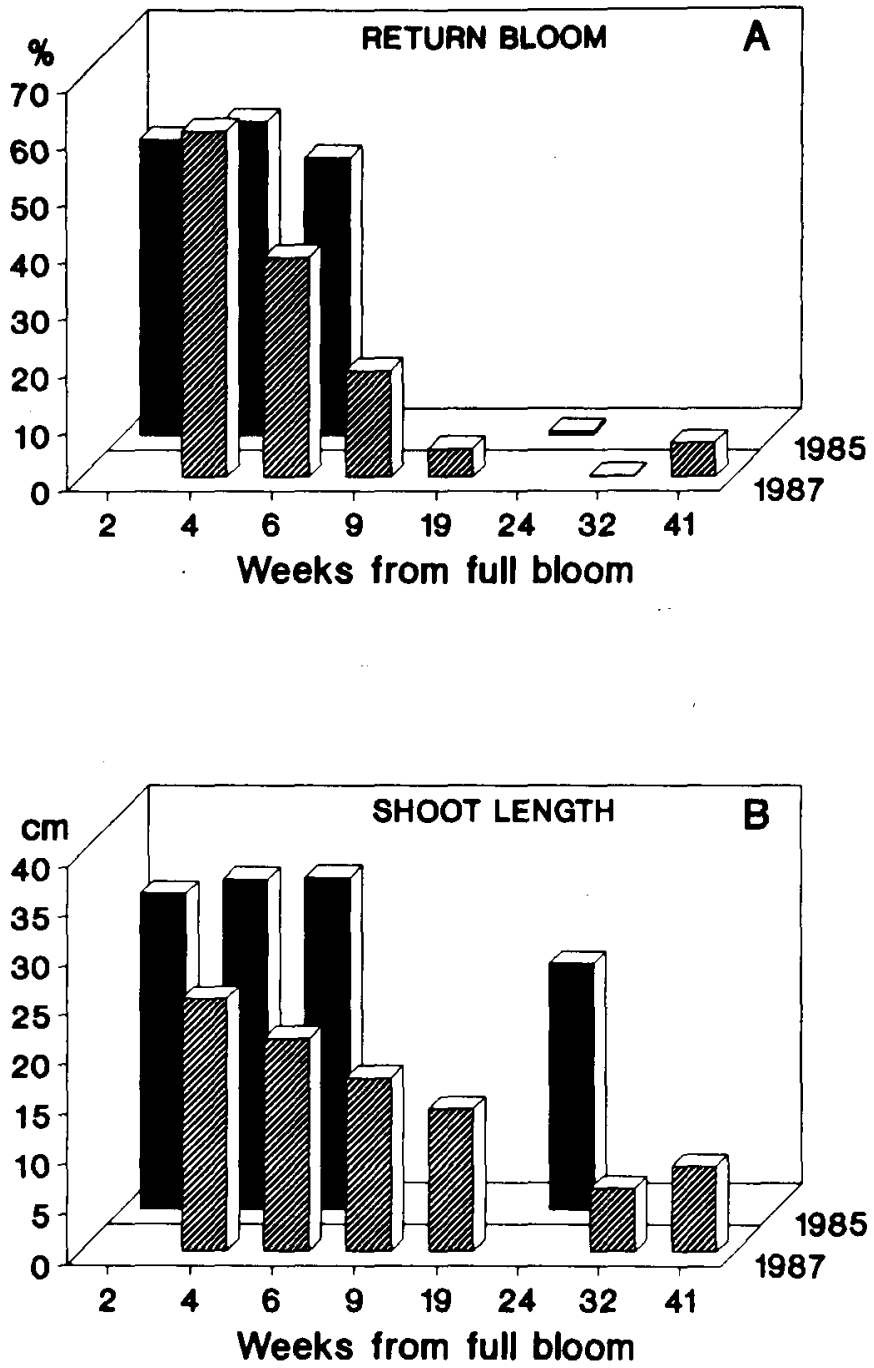

Fig. 2. Effect of fruit removal between 2 and 41 weeks AFB in 1985 and 1987 on return bloom and vegetative growth in 'Manzanillo' olives. Trends: $(\mathbf{A})$ Linear $(P=0.05)$ or quadratic $(P=0.05)$ in 1985 and linear $(P=0.001)$ or quadratic $(P=0.01)$ in $1987 ;(\mathbf{B})$ nonsignificant in 1985 and linear $(P=0.01)$ in 1987 .

results suggest that application of $\mathrm{GA}_{3}$ in November may affect primordium development, whereas earlier applications affect flower induction.

That seeds play a role in flowering is well supported (Chan and Cain, 1967; Stutte and Martin, 1986). Olive fruit removal before endocarp sclerification promoted flowering the following year, whereas fruit removal at later stages of development had no effect on return bloom (Fig. 3A). Also, seed destruction before endocarp sclerification promoted flowering in 'Manzanillo' (Table 1), as previously reported (Stutte and Martin, 1986). These results agree with those obtained with the applications of $\mathrm{GA}_{3}$ and support the hypothesis that olive flower induction occurs before endocarp sclerification.

Seed-produced GAs may inhibit flower induction, based on the fact that increases in seed GA content occur between 5 and 9 weeks AFB in several species, including apple (Malus domestics Borkh.) (Luckwill et al., 1969; Ebert and Bangerth, 1981; Marino and Greene, 1981), almond [Prunus dulcis (Mill.) D.A. Webb] (Ryugo, 1976), pear (Pyrus communis L.) (Martin et al., 1977) and mango (Ram, 1983). However, the application of paclobutrazol, an inhibitor of GA synthesis, did not affect 
Table 1. The effect of seed kill 6 weeks AFB on reproductive characteristics of six olive cultivars. ${ }^{2}$

\begin{tabular}{|c|c|c|c|c|}
\hline $\begin{array}{l}\text { Cultivar and } \\
\text { treatment }\end{array}$ & $\begin{array}{c}\text { Return } \\
\text { bloom } \\
(\%) \\
\end{array}$ & $\begin{array}{c}\text { Fruit set } \\
\text { (fruits } / \mathrm{cm} \text { ) }\end{array}$ & $\begin{array}{c}\text { Fruit wt } \\
(\mathrm{g})\end{array}$ & $\begin{array}{l}\text { Mature fruits } \\
\text { at harvest } \\
(\%)\end{array}$ \\
\hline \multicolumn{5}{|l|}{ Manzanillo } \\
\hline Control & $0.7 \mathrm{~b}$ & $0.36 \mathrm{a}$ & $3.54 \mathrm{a}$ & $0.95 \mathrm{~b}$ \\
\hline $\begin{array}{l}\text { Seed-killed } \\
\text { Rubra }\end{array}$ & $21.6 \mathrm{a}$ & $0.16 \mathrm{~b}$ & $3.41 \mathrm{a}$ & $73.8 \mathrm{a}$ \\
\hline Control & $45.8 \mathrm{a}$ & $0.38 \mathrm{a}$ & $1.40 \mathrm{a}$ & $41.8 \mathrm{a}$ \\
\hline Seed-killed & $44.5 \mathrm{a}$ & $0.04 \mathrm{~b}$ & $1.01 \mathrm{~b}$ & $55.0 \mathrm{a}$ \\
\hline \multicolumn{5}{|l|}{ Sevillano } \\
\hline Control & $15.8 \mathrm{a}$ & $0.16 \mathrm{a}$ & $5.80 \mathrm{a}$ & $6.50 \mathrm{~b}$ \\
\hline Seed-killed & $24.6 \mathrm{a}$ & $0.11 \mathrm{~b}$ & $3.71 \mathrm{~b}$ & $31.8 \mathrm{a}$ \\
\hline \multicolumn{5}{|l|}{ Ascolano } \\
\hline Control & $4.2 \mathrm{a}$ & $0.19 \mathrm{a}$ & $5.68 \mathrm{a}$ & -- \\
\hline Seed-killed & $3.8 \mathrm{a}$ & $0.14 \mathrm{a}$ & $4.84 \mathrm{a}$ & --- \\
\hline \multicolumn{5}{|l|}{ Picual } \\
\hline Control & $14.5 \mathrm{a}$ & $0.60 \mathrm{a}$ & $2.56 \mathrm{a}$ & --- \\
\hline Seed-killed & $24.5 \mathrm{a}$ & $0.20 \mathrm{a}$ & $1.69 \mathrm{a}$ & --- \\
\hline \multicolumn{5}{|l|}{ Koroneiki } \\
\hline Control & $1.01 \mathrm{a}$ & $0.84 \mathrm{a}$ & $0.61 \mathrm{a}$ & -- \\
\hline Seed-killed & $2.1 \mathrm{a}$ & $0.57 \mathrm{~b}$ & $0.43 \mathrm{a}$ & --- \\
\hline
\end{tabular}

${ }^{2}$ Mean separation within cultivars and columns by $\mathrm{F}$ test, $P=0.05$.

${ }^{\mathrm{\gamma}}$ Estimated by the amount of color change from green to purple.

flowering in olive (Fig. 2). In part, this maybe due to the small amount of paclobutrazol that transports to olive fruit (G. Costa personal communication). Paclobutrazol has not been effective in retardation of vegetative growth in the olive (Navarro et al., 1989), while it has effectively retarded vegetative growth on other crops. In fact, in California trials, olive growth retardation has never been achieved with paclobutrazol (G. C. M., unpublished). Clearly, in the trials reported here, paclobutrazol had no effect on olive return bloom or vegetative growth (Fig. 2).

These experiments were designed to test the hypothesis that olive flower induction occurs before winter dormancy. Our results show that changes related to floral induction occur around July, before the time of endocarp sclerification, and that induction can be affected by $\mathrm{GA}_{3}$ treatment, seed kill, or fruit removal before that time.

\section{Literature Cited}

Badr, S.A. and H.T. Hartmann. 1971. Effect of diurnally fluctuating vs. constant temperatures on flower induction and sex expression in the olive (Olea europaea). Physiol. Plant. 24:40-45.

Bernier, G.. 1988. The control of floral evocation and morphogenesis. Annu. Rev. Plant Physiol. Plant Mol. Biol. 39:175-219.

Chan, B.G. and J.C. Cain. 1967. The effect of seed formation on subsequent flowering in apple. Proc. Amer. Soc. Hort. Sci. 91:6368.

Drobish, H.E. 1930. Olive thinning and other means of increasing size of olives. Bul. 490 Univ. of California, Berkeley.
Ebert, A. and F. Bangerth. 1981. Relations between the concentration of diffusible and extractable gibberellin-like substances and the alternate-bearing behavior in apple as affected by chemical fruit thinning. Scientia Hort. 15:45-52.

Hackett, W.P. and H.T. Hartmann. 1967. The influence of temperature on floral initiation in the olive. Physiol. Plant. 20:430-436.

Hartmann, H.T. 1951. Time of floral differentiation of the olive in California. Bet. Gaz. 112:323-327.

Hartmann, H.T. and J.E. Whisler. 1975. Flower production in olive as influenced by various chilling temperature regimes. J. Amer. Soc. Hort. Sci. 100:670-674.

Hedden, P. and J.E. Graebe. 1985. Inhibition of gibberellin biosynthesis by paclobutrazol in cell-free homogenates of Cucurbita maxima endosperm and Malus pumila embryos. J. Plant Growth Regulat. 4:111-122.

Kachru, R. B., R.N. Singh, and E.K. Chacko, 1971. Inhibition of flowering in mango (Mangifera indica L.) by gibberellic acid. HortScience 6:140-141.

Leon, J.M. and M.J. Bukovac. 1978. Cuticle development and surface morphology of olive leaves with reference to penetration of foliarapplied chemicals. J. Amer. Soc. Hort. Sci. 103:465-472.

Lord, E.M. and K.J. Eckard. 1987. Shoot development in Citrus sinensis L. (Washington Navel orange). II. Alteration of developmental fate of flowering shoots after $\mathrm{GA}_{3}$ treatment. Bet. Gaz. 148:1722.

Luckwill, L. C., P. Weaver, and J. MacMillan. 1969. Gibberellins and other growth hormones in apple seeds. J. Hort. Sci. 44:413-424.

Marine, F. and D. W. Greene. 1981. Involvement of gibberellins in the biennial bearing of 'Early McIntosh' apples. J. Amer. Soc. Hort. Sci. 106:593-596.

Martin, G. C., F.G. Dennis, Jr., J. MacMillan, and P. Gaskin. 1977. Hormones in pear seeds. L Levels of gibberellins, abscisic acid, phaseic acid, dihydrophaseic acid, and two metabolizes of dihydrophaseic acid in immature seeds of Pyrus communis L. J. Amer. Soc. Hort. Sci. 102:16-19.

Martin, G.C. 1983. Commercial uses of gibberellins, p. 395-444. In: Alan Crozier (cd.). Biochemistry and physiology of gibberellins. vol. 2.

Monselise, S.P. and E.E. Goldschmidt. 1982. Alternate bearing in fruit trees. Hort. Rev. 4:128-173.

Navarro, C., M. Benlloch, and R. Fernandez-Escobar. 1989. Effect of paclobutrazol on growth of rooted olive cuttings. Acts Hort. 239:265-268

Navarro, C., R. Fernandez-Escobar, and M. Benlloch. 1992. A lowpressure, trunk injection method for introducing chemical formulations into olive trees. J. Amer. Soc. Hort. Sci. 117:357-360.

Pinney, K. and V.S. Polito. 1990. Flower initiation in 'Manzanillo' olive. Acts Hort. 286:203-205.

Rallo, L. and G.C. Martin. 1991. The role of chilling in releasing olive floral buds from dormancy J. Amer. Soc. Hort. Sci. 116:1058-1062.

Ram, S. 1983. Hormonal control of fruit growth and fruit drop in mango cv. Dashehari. Acts Hort. 134:169-178.

Ryugo, K. 1976. Gibberellin-like substances in the endosperm-nucellus tissues of the developing almond, Prunus amygdalus Batsch CV. Jordanolo. J. Amer. Soc. Hort. Sci. 101:565-568.

Stutte, G.W. and G.C. Martin. 1986. Effect of killing the seed on return bloom of olive. Scientia Hort. 29:107-113. 